\title{
Antimicrobial, heavy metal resistance and plasmid profile of coliforms isolated from nosocomial infections in a hospital in Isfahan, Iran
}

\author{
Vajiheh Karbasizaed $^{{ }^{*}}$, Naser Badami ${ }^{1}$, Giti Emtiazi ${ }^{2}$ \\ ${ }^{1}$ Dept. of Pathobiology, Faculty of Heath Sciences, Tehran University of Medical Sciences, Tehran, Iran. \\ ${ }^{2}$ Dept.of Biology, Isfahan University, Tehran, Iran.
}

Accepted 18 September 2003.

\begin{abstract}
The antimicrobial, heavy metal resistance patterns and plasmid profiles of Coliforms (Enterobacteriacea) isolated from nosocomial infections and healthy human faeces were compared. Fifteen of the $\mathbf{2 5}$ isolates from nosocomial infections were identified as Escherichia coli, and remaining as Kelebsiella pneumoniae. Seventy two percent of the strains isolated from nosocomial infections possess multiple resistance to antibiotics compared to $45 \%$ of strains from healthy human faeces. The difference between minimal inhibitory concentration (MIC) values of strains from clinical cases and from faeces for four heavy metals $(\mathrm{Hg}, \mathrm{Cu}, \mathrm{Pb}, \mathrm{Cd})$ was not significant. However most strains isolated from hospital were more tolerant to heavy metal than those from healthy persons. There was no consistent relationship between plasmid profile group and antimicrobial resistance pattern, although a conjugative plasmid (>56.4 kb) encoding resistance to heavy metals and antibiotics was recovered from eight of the strains isolated from nosocomial infections. The results indicate multidrug-resistance coliforms as a potential cause of nosocomial infection in this region.
\end{abstract}

Key words: Nosocomial infection, plasmid profile, antimicrobial resistance, Escherichia coli, Kelebsiella pneumoniae.

\section{INTRODUCTION}

Hospitalized patients are at unusually high risk of infections, and the hospital environment favors the acquisition of resistance to antimicrobial agents, complicating the treatment of nosocomial infections due to drug-resistant pathogens (Catalano, 1994). The pattern of hospital infection has changed over the years, reflecting advances in medicine and development of antimicrobial agents. More recently the importance of Gram-negative bacteria has increased since the advent

${ }^{\star}$ Corresponding author; Tel: 00983116245031, Fax: 00983112220283, E-mail: Va_Karbasi@yahoo.com. of broad-spectrum antibiotics because these organisms often carry multiple antibiotics resistance (Mims et al., 1999). In the recent years the application of molecular techniques for the identification and differentiation of bacterial isolates in hospitals has provided a powerful set of new tools that can augment both patient management and epidemiological investigation (Villari et al., 1998; Senerwa et al., 1991; Gakuya et al., 2001; Murono et al., 1982; Ayliff, 1982; Rasheed et al., 1997; Wallace et al., 1995).

Microorganisms that are resistant to both antibiotics and metals have been isolated from nosocomial and burn wound infection (Calomiris et al., 1984; Poiata et al., 2000). In addition to the investigation of antimicrobial 
Table 1. Antimicrobial resistance patterns of $E$. coli isolates from the nosocomial infections and faeces.

\begin{tabular}{|c|c|c|c|}
\hline \multirow[t]{2}{*}{ Group } & \multirow{2}{*}{$\begin{array}{c}\text { Isolate } \\
\text { designation• }\end{array}$} & \multicolumn{2}{|c|}{ Antimicrobial resistance pattern* } \\
\hline & & Original & Transferred \\
\hline \multicolumn{4}{|c|}{ Nosocomial E.coli } \\
\hline 1 & $\mathrm{NE}_{1}, \mathrm{NE}_{3}, \mathrm{NE}_{4}$ & $\mathrm{Te}, \mathrm{Cm}, \mathrm{Km}, \mathrm{Na}, \mathrm{SxT}, \mathrm{Cp}, \mathrm{Ap}$ & Te, SxT, Ap \\
\hline 2 & $\mathrm{NE}_{2}$ & Te, SxT, Ap & Te, SxT, Ap \\
\hline 3 & $\mathrm{NE}_{5}$ & SxT, Ap, Cf & SxT, Ap, Cf \\
\hline 4 & $\mathrm{NE}_{6}, \mathrm{NE}_{11}$ & - & - \\
\hline 5 & $\mathrm{NE}_{7}, \mathrm{NE}_{14}$ & Ap & - \\
\hline 6 & $\mathrm{NE}_{8}, \mathrm{NE}_{12}$ & $\mathrm{Te}, \mathrm{Cm}, \mathrm{Gm}, \mathrm{SxT}, \mathrm{Ap}$ & - \\
\hline 7 & $\mathrm{NE}_{9,} \mathrm{NE}_{13}$ & Te, SxT, Ap, Cm & SxT, Ap, Te \\
\hline 8 & $\mathrm{NE}_{10}, \mathrm{NE} 15$ & Ap & Ap \\
\hline \multicolumn{4}{|l|}{ Fecal E.coli } \\
\hline 1 & $\mathrm{FE}_{4}, \mathrm{FE}_{8}$ & Te, SxT, Ap & NT \\
\hline 2 & $\mathrm{FE}_{6}, \mathrm{FE}_{2}$ & SxT, Ap & NT \\
\hline 3 & $\mathrm{FE}_{1}$ & Te, Ap & NT \\
\hline 4 & $\mathrm{FE}_{9}, \mathrm{FE}_{7}$ & Ap & NT \\
\hline 5 & $\mathrm{FE}_{5}, \mathrm{PE}_{10}$ & - & - \\
\hline
\end{tabular}

NT, not tested

-NE, nosocomial E .coli; FE, fecal E. coli.

*Tested antibiotics. Ap, ampicillin; $\mathrm{Cm}$, chloramphenicl; $\mathrm{Km}$, kanamycin; SxT, trimethoprim-

sul phamethoxazole; Cf, cephalothin; $\mathrm{Gm}$, Gentamycin; $\mathrm{Cp}$, ciprofloxazin.

resistance and plasmid profile of coliforms isolated from nosocomial infections, their heavy metal resistance was also compared with isolates originating from faeces of healthy persons.

\section{MATERIALS AND METHODS}

\section{Bacterial isolates}

Twenty-five strains of coliforms (Enterobacteriaceae) involved in nosocomial infections were isolated at the Alzahra Hospital in Isfahan. Those from faeces of healthy persons $(n=20)$ were isolated in the laboratory. Bacteria were cultured on blood and MacConkey agar in aerobic condition at $37^{\circ} \mathrm{C}$ for $24 \mathrm{~h}$.Coliforms were identified with conventional biochemical tests (Forbes et al., 1998).

\section{Antimicrobial resistance testing}

The antimicrobial resistance patterns of strains were routinely tested by the single-disk diffusion method using Muller-Hinton agar against the following antibiotics: ampicilln (Ap,l0 $\mu \mathrm{g} / \mathrm{ml})$, chloramphenicol $(\mathrm{Cm}, 30 \mu \mathrm{g} / \mathrm{ml})$, trimethoprim-sulphamethoxazole (SxT, $5 \mu \mathrm{g} / \mathrm{ml})$, amikacin (Ak, $30 \mu \mathrm{g} / \mathrm{ml})$, nalidixic acid $(\mathrm{Na}, 30 \mu \mathrm{g} / \mathrm{ml})$, kanamycin $(\mathrm{Km}, 30 \mu \mathrm{g} / \mathrm{ml})$, tetracycline $(\mathrm{Te}, 3 \mu \mathrm{g} / \mathrm{ml})$, ciprofloxacin $(\mathrm{Cp}, 5 \mu \mathrm{g} / \mathrm{ml})$, cephalothin $(\mathrm{Cf}, 30 \mu \mathrm{g} / \mathrm{ml})$. Zone sizes were interpreted by using standard recommendations.

Strains isolated from nosocomial infections showing resistance to $\geq 1$ antibiotics were examined for their ability to transfer the resistance. Conjugation was performed using a coliform strain of human origin susceptible to all the drug as recipient, a resistant strain as donor (Kruse et al., 1994). Aliquots of overnight cultures of donor and recipient organisms were mixed in a final volume of 10 $\mathrm{ml}$ brain-heart infusion broth. The mixture was incubated at $37^{\circ} \mathrm{C}$ for $4 \mathrm{~h}$, and a sample was removed and plated on eosin-methylen blue medium containing the appropriated antibiotics. The plasmid DNA of transconjugant was analyzed on agarose gel in order to see whether the presence of the requisite plasmids correlated with the phenotype.

\section{Heavy metal resistance testing}

All isolates were also tested to determine the minimal inhibitory concentrations (MICs) of four metals (Forbes et al., 1998). The experimental tubes were prepared by supplementing Muller-Hinton medium with metal salts for cationic concentrations of 2.7, 13.57, $27.15,54.3 \mu \mathrm{g} / \mathrm{ml}$ for $\mathrm{Hg}^{2+} ; 12.5,25,50,100,200,400,800 \mu \mathrm{g} / \mathrm{ml}$ for $\mathrm{Cd}^{2+} ; 400,800,1600,2400,3200 \mu \mathrm{g} / \mathrm{ml}$ for $\mathrm{Pb}^{2+}$; and 100, 200, $400,800,1600,3200,6400 \mu \mathrm{g} / \mathrm{ml}$ for $\mathrm{Cu}^{2+}$. The compounds were $\mathrm{CuSO}_{4}, \mathrm{~Pb}\left(\mathrm{NO}_{3}\right)_{2}, \mathrm{CdSO}_{4}$, and $\mathrm{HgCl}_{2}$. One milliliter of the test organism suspension $\left(1 \times 10^{6} \mathrm{CFU} / \mathrm{ml}\right)$ was added to each tube. The tubes were incubated for $18 \mathrm{~h}$ at $35^{\circ} \mathrm{C}$ and visual turbidity is noted. An aliquot of $0.1 \mathrm{ml}$ from nonturbidal tubes is subcultured to agar for determining MBC. 
Table 2. Antimicrobial resistance patterns of $K$. pneumoniae isolates from the nosocomial infections and faeces.

\begin{tabular}{|c|c|c|c|}
\hline \multirow[t]{2}{*}{ Group } & \multirow{2}{*}{$\begin{array}{c}\text { Isolate } \\
\text { designation• }\end{array}$} & \multicolumn{2}{|c|}{ Antimicrobial resistance pattern* } \\
\hline & & Original & Transferred \\
\hline \multicolumn{4}{|c|}{ Nosocomial K. pneumoniae } \\
\hline 1 & $\mathrm{NK}_{1}$ & $\mathrm{Km}, \mathrm{Ap}$ & - \\
\hline 2 & $\mathrm{NK}_{2}$ & $\mathrm{Ap}$ & - \\
\hline 3 & $\mathrm{NK}_{3,} \mathrm{NK}_{8}$ & $\mathrm{Km}, \mathrm{Gm}, \mathrm{Na}, \mathrm{An}, \mathrm{Ap}$ & - \\
\hline 4 & $\mathrm{NK}_{4}$ & $\mathrm{Km}, \mathrm{Gm}, \mathrm{Cm}, \mathrm{Te}, \mathrm{Cf}, \mathrm{Ap}$ & - \\
\hline 5 & $\mathrm{NK}_{5}, \mathrm{NK}_{7}$ & $\begin{array}{l}\mathrm{Km}, \mathrm{Cm}, \mathrm{Te}, \mathrm{An}, \mathrm{SxT}, \mathrm{Cp}, \mathrm{Cf} \\
\mathrm{Ap}\end{array}$ & $\mathrm{Te}, \mathrm{SxT}, \mathrm{Ap}, \mathrm{Cm}$ \\
\hline 6 & $\mathrm{NK}_{8}$ & SxT, Ap & - \\
\hline 7 & $\mathrm{NK}_{9}, \mathrm{NK}_{10}$ & Te, SxT, Ap & Te, SxT, Ap \\
\hline \multicolumn{4}{|c|}{ Fecal K. pneumoniae } \\
\hline 1 & $\mathrm{FK}_{2}, \mathrm{FK}_{6}$ & SxT, Ap, Gm & NT \\
\hline 2 & $\mathrm{FK}_{1}, \mathrm{FK}_{3}, \mathrm{FK}_{7}, \mathrm{FK}_{10}$ & Ap & NT \\
\hline 3 & $\mathrm{FK}_{4}, \mathrm{FK}_{8}$ & $\mathrm{Te}, \mathrm{Ap}$ & NT \\
\hline 4 & $\mathrm{FK}_{5}, \mathrm{FK}_{9}$ & - & - \\
\hline
\end{tabular}

$\mathrm{NT}$, not tested

-NK, nsocomial K. pneumoniae; FK, fecal K. pneumoniae.

*Tested antibiotics. Ap, ampicillin; Cm, chloramphenicl; Km, kanamycin; SxT, trimethoprim-

sul phamethoxazole; Cf, cephalothin; Gm, Gentamycin; Cp, ciprofloxazin.

\section{Plasmid analysis}

Plasmid DNA was extracted from cultured cell using the alkalineSDS method (Johnson, 1998). Plasmid size was estimated by comparison with previously characterized plasmids. Statistical analyses of the data were performed by a comparison of proportions by Mann-Whithney test, with confidence levels of $5 \%$ being considered significant.

\section{RESULTS}

Twenty-five coliform isolates involved in nosocomial infections and 20 isolates were from the faeces of healthy persons were tested in this study. Fifteen of the isolates from nosocomial infections identified as Escherichia coli and the remaining as Kelebsiella pneumoniae. The most common nosocomial infections were urinary tract (15 cases), blood stream (5 cases), respiratory tract ( 3 cases) and skin infection (2 cases).

\section{Antimicrobial drug resistance}

Tables 1 and 2 summarize the antimicrobial susceptibility patterns of the coliform isolates. In the fifteen strains of pathogenic E. coli, resistance to ampicilin (100\%), Trimethoprim-sulphamethoxazole (73.3\%), tetracycline (53.3\%), chloramphenicol $(46.6 \%)$, kanamycin $(20 \%)$, gentamycin $(13.3 \%)$, ciprofloxacin $(20 \%)$, nalidixic acid $(20 \%)$, and cefalothin $(6.6 \%)$ was encountered. A total of $11(84.6 \%)$ of the resistant isolates were multiple drugresistant. Multiple drug resistance was also common $(90 \%)$ in K. pneumoniae_strains isolated from nosocomial infections. Frequency of antimicrobial resistance among the $K$. pneumoniae isolates was as follows: ampicillin $(100 \%)$, tetracycline $(50 \%)$, kanamycin $(60 \%)$, trimethoprim-sulphamethoxazole $(40 \%)$, chloramphenicol $(30 \%)$, gentamycin $(30 \%)$, cefalothin $(30 \%)$, and nalidixic acid $(20 \%)$. All strains were sensitive to ciprofloxacin.

Antimicrobial resistance was not distributed uniformly. Thirteen $(56.5 \%)$ of 23 resistant strains from nosocomial infections transferred their drug resistance to recipient cells.

\section{Heavy metal resistance}

By stringent criteria, the MIC was designated to be a twofold dilution of the heavy metal ion concentration with inhibited the growth of the tested bacteria in Muller- 
Hinton Broth. MIC values indicative of metal tolerance were $200 \mu \mathrm{g} / \mathrm{ml}$ for $\mathrm{Cd}^{2+}, 3200 \mu \mathrm{g} / \mathrm{ml}$ for $\mathrm{Pb}^{2+}, 54.3 \mu \mathrm{g} / \mathrm{ml}$ for $\mathrm{Hg}^{2+}$ and $1750 \mu \mathrm{g} / \mathrm{ml}$ for $\mathrm{Cu}^{2+}$. The differences between MIC values of strains from clinical cases and strains from faeces for heavy metals were not significant. However most strains isolated from the hospital were more tolerant to heavy metal than ones isolated from healthy human faeces.

\section{A.}

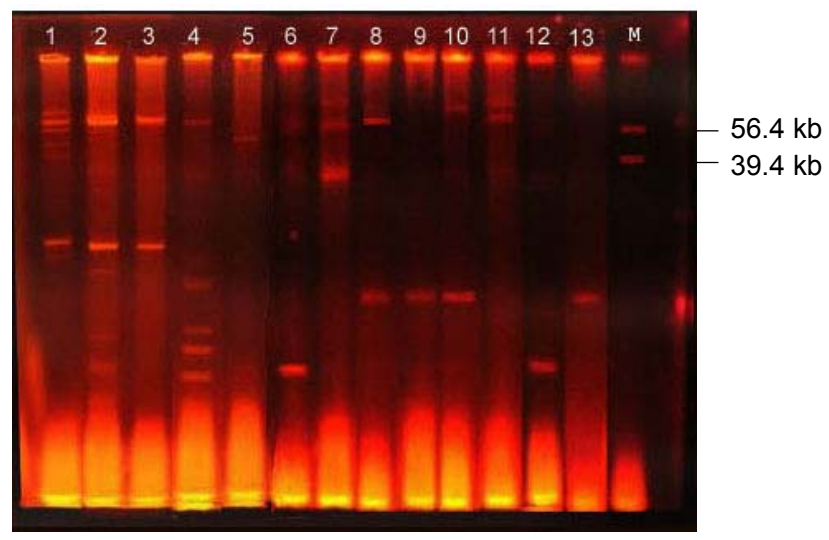

B.

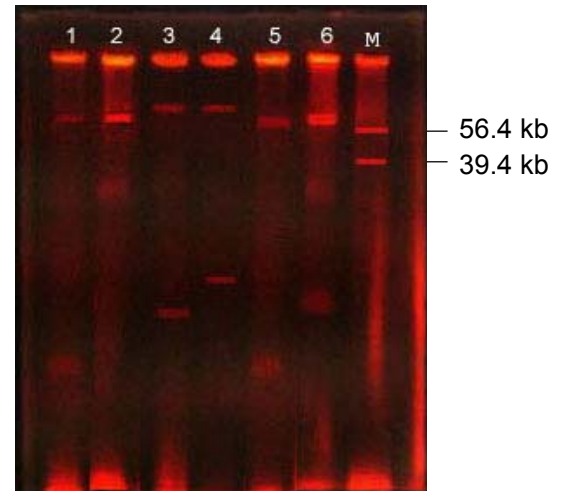

Figure 1. Plasmid profiles of coliforms isolated from nosocomial infection. (A) E.coli strains. Lanes: $1, \mathrm{NE}_{1} ; 2, \mathrm{NE}_{2} ; 3, \mathrm{NE}_{3} ; 4, \mathrm{NE}_{4}$; 5, $\mathrm{NE}_{5} ; 6, \mathrm{NE}_{7} ; 7, \mathrm{PE}_{8} ; 8, \mathrm{NE}_{9} ; 9, \mathrm{NE}_{10} ; 10, \mathrm{NE}_{12} ; 11, \mathrm{NE}_{13} ; 12$, $\mathrm{NE}_{14} ; 13, \mathrm{NE}_{15} ; \mathrm{M}$, molecular size marker (E.coli 39R 861 plasmid, and $\mathrm{RP}_{1}$ plasmid $56.4 \mathrm{~kb}$ ). (B) K. pneumoniae strain. Lanes: $1, \mathrm{NK}_{9}$; 2, $\mathrm{NK}_{10} ; 3, \mathrm{NK}_{7} ; 4, \mathrm{NK}_{8} ; 5, \mathrm{NK}_{3} ; \mathrm{M}$, molecular size marker (E.coli 39R 861 plasmid, $39.4 \mathrm{~kb}$ and $\mathrm{RP}_{1}$ plasmid $56.4 \mathrm{~kb}$ ).

\section{Plasmid DNA studies}

In most of the 25 strains of coliforms isolated from nosocomial infections, plasmids of different molecular size were found (Figure 1). In several cases different isolates showed very similar plasmid profiles. Strains susceptible to antibiotics were negative for plasmids. Although 19 isolates contained plasmids, the presence of transferable R plasmid among them was detected only in
$13(68.4 \%)$. Eight of these strains harboured a conjugative plasmid (>56.4 kb). The plasmid conferring $\mathrm{Te}, \mathrm{SxT}$, and Ap resistance pattern was also repeatedly found in transconjugants. Transfering this plasmid to recipient cells increases MIC values for heavy metals 5fold for $\mathrm{Hg}^{2+}$, 4-fold for $\mathrm{Pb}^{2+}$, and 2-fold for $\mathrm{Cd}^{2+}$. Twelve out of the 20 coliform strains isolated from fecal origin carried plasmid. Among these, plasmids of $\leq 56.4 \mathrm{~Kb}$ were most frequent (Figure 2). There was no consistent relationship between plasmid profile and antimicrobial resistance pattern.

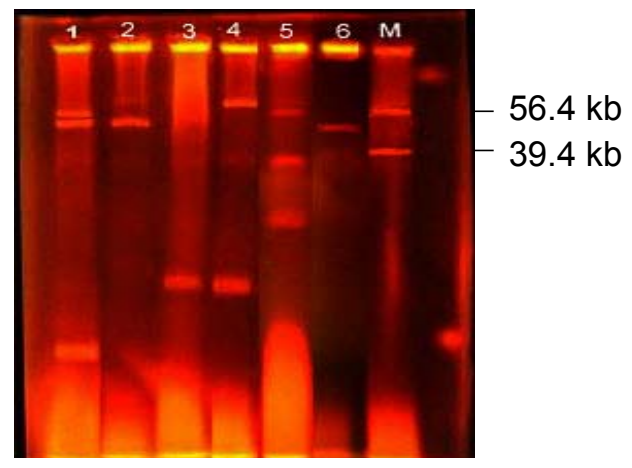

Figure 2. Plasmid profiles of coliforms isolated from healthy human faeces. Lanes: $1, \mathrm{FE}_{1} ; 2, \mathrm{FE}_{4} ; 3, \mathrm{FE}_{5}$; 4, $\mathrm{FE}_{7} ; 5, \mathrm{FK}_{2} ; 6, \mathrm{FK}_{4} ; \mathrm{M}$, molecular size marker (E.coli 39R 861 plasmid, $39.4 \mathrm{~kb}$ and $\mathrm{RP}_{1}$ plasmid $56.4 \mathrm{~kb})$.

\section{DISCUSSION}

A high frequency of resistance among $E$. coli and $K$. pneumoniae strains isolated from nosocomial infections to antibiotics was observed in the present study. Similar results have also been obtained in other studies (Murdoch et al., 1995; Araque et al., 2000). Most of these isolates carried plasmids and resistance to antimicrobials are mostly plasmid-mediated (Forster, 1983). Of the nine antibiotics tested in this study, there was a significant difference between $E$. coli and $K$. pneumoniae strains with regards to resistance. The frequency of resistance to gentamicin, kanamycin and cephalothin is higher in $K$. pneumoniae than E. coli strains. Wallace et al. (1995) also reported increased frequencies of resistance among nosocomial strains of $K$. pneumoniae to these antibiotics.

Our results show multi-resistant strains had higher MIC values compare to the sensitive ones. The strains isolated from hospital were more resistant to metals and antibiotics than strains from human faeces. Positive correlations between tolerance to high levels of $\mathrm{Cu}^{2+}$, $\mathrm{Pb}^{2+}, \mathrm{Zn}^{2+}$ and multi-resistant bacteria isolated from drinking water have previously been reported (Calomiris 
et al., 1984). Furthermore, we found that some enterobacteria isolated from nosocomial infections harboured a conjugative plasmid (>56.4 kb) encoding resistance to antibiotics and heavy metals. Ghosh et al. (2000) have also reported on transferable plasmids encoding resistance to various heavy metals and antibiotics of Salmonella abortus equi.

In spite of the wide range of plasmids present in the bacterial isolates from nosocomial infection, there was no consistent correlation between plasmid profiles and antibiotic resistance pattern. This is not unexpected since the same antimicrobial resistance pattern can be encoded by unrelated plasmids, transposons, phages and chromosomal genes. Antibiotic resistance pattern and plasmid profile are sometimes inadequate to clarify the relationships between different clinical isolates from a single hospital and can lead to erroneous epidemiologic conclusion (Dombrovskii, 1990). In conclusion, our data indicate that multidrug resistant nosocomial infection is be coming an important problem, especially taking into account the limited choice of antimicrobial agents for treatment and the possibility of transfer of resistance to other enteric organisms.

\section{REFERENCES}

Ayliff G (1982). Hospital acquired infection. Am. J. Med. 63:234-52.

Araque M, Nieves B, Lauretti L, Rossolini G (2000). Molecular basis of extended-spectrumbeta-lactamase production in nosocomial isolates of Klebsiella.pneumoniae from Venezuela. Int. J. Antimicrob. Agents15:34-42.

Catalano M (1994). Bacterial genotyping in nosocomial infections. Medicina 54:590-604.

Calomiris J, Armstrong L, Seidler J (1994). Association of metal tolerance with multiple antibiotic resistance of bacteria isolated from drinking water. Appl. Environ. Microbiol. 47:1238-1242.

Dombrovskii M (1990). Analysis of plasmid profile of antibiotic resistant Enterobacteriaceae circulating in hospitals. Antibiot. Chemother. 35:289.

Forbes BA (1998). Enterobacteriaceae. Baily and Scott's Diagnostic Microbiology.Baltimor, Mosby, pp. 509-526.

Forster TJ (1983). Plasmid mediated resistance to antimicrobial and toxic metal in bacteria. Microbiol. Rev. 47:361-409.

Gakuya F, Gakuya F, Kyule M, Gathura P (2001). Antimicrobial susceptibility and plasmids from Escherichia coil isolates from rats. East. Afr. Med. J. 78:518-522.

Ghosh A, Singh A, Ramteke P, Singh V (2000). Characterization of large plasmids encoding resistance to toxic heavy metals in Salmonella.abortus equi. Biochem. Biophys. Res. Commun. 272:611.

Johnson P (1998). Plasmid analysis. In: Johuson AP, Woodford N Molecular bacteriology protocols and clinical applications. Humana Press Inc., Totowa, pp. 51-62.

Kruse H, Sorum H (1994). Transfer of multiple drug resistance plasmids between bacteria of divers origins in natural microenviroments. Appl. Environ. Microbiol. 60: 4015-4021.

Mims C, Playfair J, Roit I, Wakelin D, Williams R (1999). Hospital infection, Sterilization and Disinfection. In: Mims C. (ed.) Medical Microbiology. Landon, Mosby, pp. 482-483.

Murono K, Fujita K, Yoshikawa M, Saijo M, Inyaku F, Kakehashi H, Tsukamoto T (1993). Acquisition of nonmaternal enterobacteriaceae by infants delivered in hospitals. J. Pediater. 122:120-125.

Murdoch DA, Spillman I, Kabare P (1995). Antibiotic availability and multiresistant coliforms in a rural Uganda hospital. J. Trop. Med. Hyg. 98:25-28.
Poiata A, Badicut I, Indres M, Biro M, Buiue D (2000). Mercury resistance among clinical isolate of Escherichia coli. Roum. Arch. Microbiol. Immunol. 59:71-79.

Rasheed J, Jay C, Metchock B, Berkowitz F, Weigel L, Crellin J, Steward C, Hill B, Medeiros A, Tenover F (1997). Evolution of extended -spectrum beta-lactam resistance (SHV-8) in a strain of Escherichia coli during multiple episodes of bacteremia. Antimicrob. Agent. Chemother. 41:647-653.

Senerwa D, Mutanda L, Gathuma J, Olsvic O (1991). Antimicrobial resistance of enteropathogenic Escherichia coli strains from a nosocomial outbreak in Kenya. APIMS 99:728-734.

Villari P, lacuzio L, Torre I, Scarcella A (1998). Molecular epidemiology as an effective tool in the surveillance of infection in neonatal intensive care unit. J. Infect. 37:274-281.

Wallace MR, Johnson A, Daniel M, Malde M, Yousif A (1995). Sequential emergence of multi-resistant Klebsiella. pneumoniae in Bahrain. J. Hosp. Infect. 31:247-252. 